\title{
Analysis of the Effectiveness of E-Government in the Federal Government of Nigeria
}

\author{
Robert A. Dibie, Ph.D. (Corresponding author) \\ Professor of Public Policy, Public Management and Environmental Studies \\ Department of Public Administration and Health Management \\ Indiana University Kokomo \\ Kokomo, USA \\ Maryam O. Quadri, Ph.D. \\ Senior Lecturer \\ Department of Political Science and Public Administration \\ University of Lagos \\ Lagos, Nigeria
}

Received: May 24, 2018 Accepted: July 12, 2018 Online published: July 31, 2018

doi:10.5296/jpag.v8i3.13454ＵRL: https://doi.org/10.5296/jpag.v8i3.13454

\begin{abstract}
This paper examines the nature, impact, effectiveness and barriers of e-government in the Federal Government of Nigeria. It also explores the extent to which e-government has facilitated a better relationship between citizens and the federal government of Nigeria. It argues that the utilization of technologies such as internet, email, websites, and social media have yet to effectively connect citizens, and the government. As a result, the federal government of Nigeria has not fully adopted the new e-government approaches to improve its services. The paper uses data derived from questionnaire survey administered to 3,000 Nigerian citizens including federal government staff in Abuja, Lagos and some state capitals in Nigeria., Interviews of 300 federal officials and stakeholders were conducted. The secondary data consisted of the review of related government reports, government websites, academic and professional journals. Data were analyzed to determine the impacts of e-governance in the federal government. The conceptual framework is based on stakeholders' theory, and an integrated e-government model. The findings suggest that on one hand there is a negative
\end{abstract}


correlation between the e-governance initiatives and federal government efficient service delivery in Nigeria. On the other hand, there is also a negative correlation between citizens and federal government relations in the country. Some challenges preventing the adoption of proactive e-governance practices were identified and recommendations for appropriate policies that could address the current impediments were offered.

Keywords: e-government, e-governance, electronic democracy, government-citizen relationship, principal-agent relationship, sustainable development, Nigeria

\section{Introduction}

In almost all the countries in the world, government is more than a part of life, it is a necessity to all citizens. In the twenty-first century governments ensures that their respective countries' citizens are secured by enacting public policies through the political system. Some countries have been very fortunate to have government with a social conscience that have galvanized their society to develop, while others have not been able to build positive relations with their citizens. The new public management concept is innovative and ambitious because it heralds a major change in the role of government in sustainable development. In order to solve the major problems that the Federal Government of Nigeria has experience for several decades with bureaucratic governance, the is a new orientation towards empowerment, competition, and meeting the needs of the citizens. The components of performance management and faster service delivery in the public sector in Nigeria now encompass e-government (Dibie 2018; Henry 2017; Ni Ya \&Van Wart 2016).

Understanding how government deliver services with technology and the democratic processes that they must follow entails substantial aspects of production, distribution and supply and demand (Dibie, 2018). It does not matter whether citizens are awake or asleep, in the rural, local, state, urban or federal territories respectively some element of government services or regulatory functions of public administrators affects the lives of everyone. According to Hill and Lynn (2016) in all ramifications the public interacts with public administrators as clients or customers or both. The significance of the client or customer relationship is that the citizens seek to obtain a benefit or service from public administrators from different departments, ministries or agencies. E-government has been introduced for almost five decades to establish a better client, customer, citizens and public administrators' relations and efficiency than it has been in the past. Some scholars have argued that e-government has effectively increased citizens' ability to apply for government services, seek permits or licenses, pay taxes and utility bills, fill out application for government services and jobs, and pay fines online (Calista \& Melitski 2007; O’Brien \& Marakas 2011; Zussman 2002). Despite, the requirement of e-government to help public administrators and citizens to increase transaction and other related business online, it has also been argued that in some cases people still need to meet face to face with a public administrator to address their respective needs (Rosenbloom 2009; Shafritz et al 2017).

E-government refers to the efforts of government to use internet to simply its activities for both the citizens and public administrators (Holzer \& Schwester 2016; Cloete 2003; Calista $\&$ Melitski 2007). According to Shark (2008) and Shafritz et al (2017) e-government has two 
components. On one hand, is the internal requirement to use internet and electronic procurement to deliver services online, and Web-based management of information systems. On the other hand, is the external online services, such as bill payment portal, community calendars, and application forms for employment, that is offered to citizens and businesses (Shafritz et al 2017; Bhatnagar et al 2010).

Some scholars have argued that most government in the African continent are inherently conservative in both promoting the constitutional rights of their citizens and managing government services in a transparent and accountable manner (Okwueze 2010; Olufemi 2012; Nkwe, 2012). As a result of this challenge in promoting customer service, most governments officers prefer to adopt the older technologies because they prefer to wait until a better source of electricity is assured (Dibie et al 2018; Denhardt et al 2014). There are only few countries in Africa where prudent public administrators and political leader have taken appropriate steps to adopt new technologies (Bwalya 2017; Otubu 2009). These major challenges are the reasons why the Federal Government of Nigeria has made some efforts in the past two decades to catch-up with how e-commerce have been successfully practiced in some developed countries (Dibie, 2018).

As a result of the impediment in measuring the productivity of some organizations in many countries in Africa due to lack of clear definition of outputs and quantifying mechanism, governments have increasingly turned to technology including social network to help them meet the demands of citizens (Adeyemo 2011; Babatola 2013; Shafritz et al 2017). According to the Congressional Research Service report of (2003), in the process of adopting e-government initiatives public administrators have sought to make government more accessible to citizens while simultaneously increasing efficiency and productivity. It has also been argued that new technology has a potential to increase public service delivery systems in many developing countries hence e-government initiatives have been lunched (Pathak et al 2008; West 2004; Guha \& Chakrabarti 2014). Wong and Welch (2004), Schuppan (2009, and Shafritz et al (2017) contend that one-stop government initiative have also help to simplify the complexities of massive bureaucracies by leveraging the power of contemporary information technologies such as the internet. One-stop government as used in this paper refers to an integration of public services from the point of view of the citizens.

Okwueze (2010) and Olufemi (2012) also presented the argument that the common experience of being pushed from one federal ministry or department to another often prevented the Nigerian government from rendering appropriate services to its clients (stakeholders) in a timely manner. This unprofessional approach to doing public business has made the citizens to develop unfavorable thoughts about their national government effectiveness.

According to Dibie (2014) and Dibie, (2018) budget constraints are a part of the major challenge in the Federal Government of Nigeria. As a result of this problem citizens view their national government as bloated, wasteful, and unresponsive to their most pressing needs such as clean water and electricity. Unfortunately, these constraints have made some public administrators to turn to technological fixes to maintain the quality of services without 
increased appropriation of revenue. Although, the Federal Executive Council (FEC) of Nigeria passed the Nigerian National Information Technology (NNIT) policy in 2001, many ministries and agency are still providing services to citizens in the traditional format (Nkwe 2012; Orihuela \& Obi, 2007). Even though the Nigerian National Information Technology Act of 2001 formally established infrastructure to assist in the evolution of e-government throughout the country corruption, and mis-appropriation of funds have not made transformation to take place as intended (Olatokun, 2012).

What is missing in the current literature of e-governance in Nigeria is that electronic communication revolution has not profoundly changed public management in the country. The success of e-government in the Federal Government will depend on good people, good software, good structure, good administrative ethics, code of conduct and regular electricity supply. According to Pathak et al (2008); West (2004); Otubu (2009) and Olatokun, (2012), it could be argued that the advent of the internet, cable or other digital electronic devices have incrementally galvanizing the use of electronic commerce and e-governance in Africa and Nigeria in particular. Further, public administrators at the federal government are not yet too keen to explore other electronic opportunities and the security issues that makes administering retirements programs, collecting taxes, enforcing regulations and sharing information with all the public in the country faster than it used to be. This challenge is a more difficult task than the private sectors already encounters in the country. On a positive note however, the evolution of e-government in the country brings hope that government can transform (Grimsley \& Meehan 2007; Heeks 2008). This paper is very significant because it explores the dynamics and impacts of the two faces of e-government on the people in Nigeria. It also provides a better understanding of how important e-government has been incrementally introduced in the communication network between the federal governments and its stakeholders in the country.

The goal of this paper is to examine the nature, impacts, effectiveness and barriers of e-government in the Federal Government of Nigeria. It also explores the extent to which e-government has facilitated a better relationship between citizens and the federal government of Nigeria. It argues that the utilization of technologies such as internet, email, websites, and social media have yet to effectively connect citizens, and the government. As a result, the federal government of Nigeria has not fully adopted the new e-government approaches to improve its services. The paper uses data derived from questionnaire survey administered to 3,000 Nigerian citizens including federal government staff in Abuja, Lagos and some state capitals in Nigeria. Interviews of 300 federal officials and stakeholders were conducted. The secondary data consisted of the review of related government reports, government websites, academic and professional journals. Data were analyzed to determine the impacts of e-governance in the federal government. The conceptual framework is based on stakeholders' theory, and an integrated e-government model. The findings suggest that on one hand there is a negative correlation between the e-governance initiatives and federal government efficient service delivery in Nigeria. On the other hand, there is also a negative correlation between citizens and federal government relations in the country. Some challenges preventing the adoption of proactive e-governance practices were identified and 
recommendations for appropriate policies that could address the current impediments were offered.

\section{Conceptual Framework}

The new public management principle has transformed the capacity of many governments to deliver goods and services since e-government was introduced in several countries around the world (Shark 2016; Holzer \& Schwester 2016). The e-government Act or public policies by many African countries postulated the commitment of each nation to expand the use of internet platforms in the delivery public services as well as to make government citizen-centered, resulted-oriented, and market based (Henry 2013; Heeks 2002). The major strategic plan of the e-government initiatives as spell-out in the respective public policies is to provide high-quality customer service regardless of whether the citizens contact governments' ministries, department or agencies by telephone, in person, or on the Web (Rosenbloom et al 2015). These initiatives were expected to cut government operating cost, provide citizens with easy access to government services, and make government more transparent and accountable (Milakovich \& Gordon, 2013).

The stakeholder theory contends that government as an organization is made up of different groups of people called stakeholders (Freeman 1984). According to the theory individuals and groups seek common services and administrative actions from government. It also explained how the government as an organization should make attempt to satisfy the needs, interest and viewpoint all the groups that it serves. Government stakeholders include members of the executive, legislative, and judicial branches, public administrators, all elected officials, civil society members, businesses, vendors, citizens, organized and unorganized interest groups affected by decisions of federal, state and local governments ((Freeman 1984; Ni Ya \& Van Wart 2016; Henry 2017; Rosenbloom et al 2013). This also applies to all those having a stake in the outcome of public policies (Rosenbloom et al 2013; Milakovich \& Gordon, 2013).

$\mathrm{Ni}$ Ya and Van Wart (2016) contend that government stakeholders encompass all those seeking from government various policies, regulations, and actions. This includes private contractors who perform services or produce goods for public agencies, mass-media personnel, watchdog, whistleblowers and members of the society. According to Nwanji and Howell (2007) the principle of stakeholder fairness provides a defensible source of moral obligations among citizens that has been missing in the public administration literature. Therefore, it could be argued that e-government must contribute to both citizens prosperity and accountability. The safeguard of all stakeholders' interests also means that governments should treat everyone equally, protect the rights of everyone with equal vigor, prevent discrimination in the provision of public services by e-governments. Safeguarding citizens' right and dignity requires everyone to have equal rights to recourse and remedy if there is discrimination by public officials (Kristen 2015; World Bank 2001; Yusuf 2005). Figure 1 shows the dynamics of stakeholders and e-government complexities in Africa. 


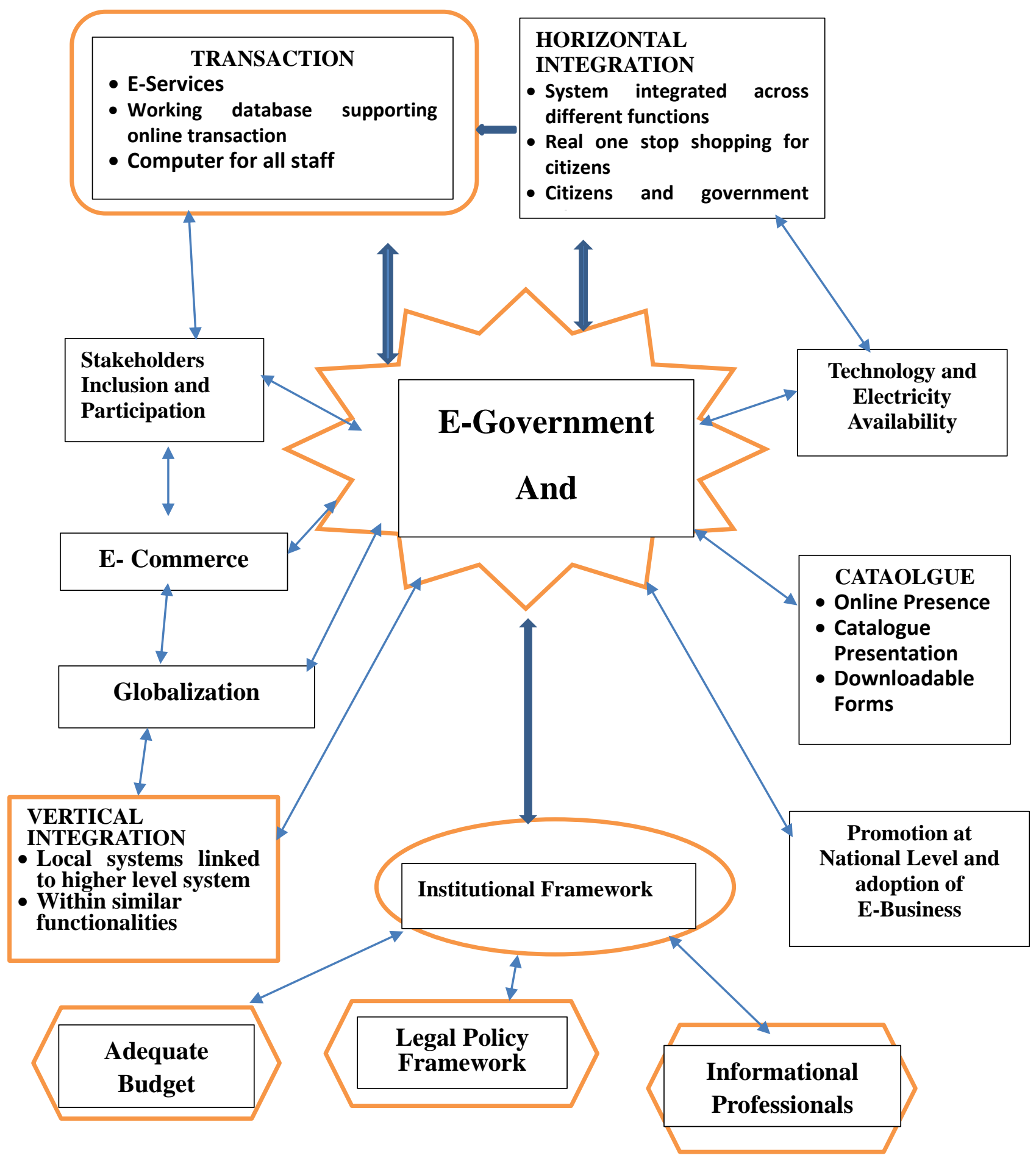

Figure 1. The Dynamics of Stakeholder and E-Government Complexity in Africa

Source: Model drawn by Dibie, R. (2018) using concept from Freeman, R.E. (1984). Strategic Management: A stakeholder Approach. Boston, USA: Pitman. Lau, E. (2003). Challenges for EGovernment Development, 5th Global Forum on reinventing Government, Mexico City, 5th (November). Fang, Z. (2002). E-Government in Digital Era: Concept, Practice and Development." International Journal of the Computer, Vol. 10 (2), pp. 1-22.

Figure 1 shows that e-government, e-commerce and stakeholders' relations are essential 
mechanism for democracy and development. A knowledgeable society requires both businesses and the government to work collaboratively to serve all their stakeholders equitably. Figure 1 also show that government could interact with citizens, business and other governments such as state, local and special districts in a routine manner through websites, emails, and interactive voice system rather than in person or writing letters. In addition, the figure shows the way a new technology initiative, may migrate from creation to use by all stakeholders. It is very important to note that both e-government and e-commerce are introduction of innovations in modern technology. Although e-government enables better service delivery in terms of information and data sharing, it also involves transactions between government, business, citizens and other stakeholders. Many scholars have argued that e-commerce, e-business and e-citizen are subsets of e-government, this is because e-government involves the delivering of a wider function than both e-commerce and e-business in several developing countries including Nigeria (Ashaye 2012; Abdallah \& Fan 2012; Adeyemo 2011; Dawes 2010; Dode 2007).

Through citizens and stakeholders' awareness of all government activities, they could become more knowledgeable to demand accountability and transparency or full access to public information. Stakeholders need to know more about the functions of government, in order to hold it answerable for its actives. On the other hand, governments need to provide access to such information (Ya Ni. \& Van Wart, 2016). In Nigeria, the lack of accountability of the government and political leaders is an issue that is dragging the nation's development backward. For the country to be truly regarded as a democratic government, this major challenge must be addressed. Further, public sector agencies should be liberated from the constrains and the requirements to equitably allocate resources and provide services that are in the best interest of all citizens in the country.

According to the triangular relation model, e-government, e-commerce are innovations in modern technology. Both business and government work collaboratively to serve the customers and civil society (Ashaye 2014; Fang 2002; Lau 2005). The triangle relations model could serve as a framework for public policy making and the implementation processes in the sense that it provides practical guidelines. In addition, the institutional theory also explained how the structure of institutions are constructed because of the uncertainties involved in stakeholders or human interaction (Robey \& Boudreau, 1999; Scott, 1995). The theory also argues that institutions are developed to galvanize interaction within the structure. Freeman (1984) contends that institutions should be regarded as a group of stakeholders relating with each other, and the mission of all institutions is to effectively manage the interests, viewpoints, wants and needs of its stakeholders. In the case of e-government in Nigeria, the main groups are customers, civil servants, federal government employees, states and local communities, suppliers and distributors, and stakeholders. According to Freeman et al (2012) there is a clear relationship between stakeholders and the institutions that they do business with. Although the institutional theory has been praised to be a central analytical mechanism for investigating the role of larger social and historical structures of information system adaptation, some scholars have argued that it does not explicitly account for how public administrators implement information communication and technology initiatives in 
government (Ashaye 2014; Peter 2000; Jensen et al, 2008). A robust approach would entail forging a collaborative environment with government and its numerous stakeholders.

The review of the literature of e-government in Africa reveals that there is limited literature in the implementation of e-government services in Nigeria and most countries in the continent. The comprehensive barrier framework was adopted from Lam's (2005). The comprehensive barrier framework is very significant for explaining some of the barriers of e-government and information systems initiatives currently encountered in Africa. The framework also systematically juxtaposed the nature of e-government services that necessitates closer working relationships between government and stakeholders (Zhang et al 2005; Mundy \& Musa 2010). One other challenge however is that there is no unified theory that focus on e-government implementation (Rorissa \& Demissie 2010; Osawe 2015). As a result of this gap in the literation, the authors of this paper tried to combine the comprehensive barrier framework, and institutional theory with other models to form a holistic concept map in explaining the nature of e-government initiatives and implementation in Africa. Figure 1 is used to explain the current framework that combines environmental factors as well as implementation benefits, barriers, and risks influencing e-government implementation within institutional context of the federal government of Nigeria. One major outcome of this research is that e-government initiatives are clustered around two factors (external and internal) in Nigeria. The external factors are government institutions, political, economic, legal, and critical mass. The internal factors include informational technology capacity, informational professionals, adequate budget, attitude and network collaboration, policy framework and lack of the promotion of e-commerce at the federal government level (Ajibade et al 2017; Dibie et al 2015). The Federal Government of Nigeria can only achieve its e-government initiatives goals if it promotes both e-commerce and e-government as the new methods of service delivery. There is also the urgent need for the national government of Nigeria to address its electricity problems, provide appropriate information communication technology infrastructure: e-readiness, computer literacy, and modern telecommunication equipment.

\section{Research Method}

The purpose of this paper is to examine the nature, impact effectiveness and barriers of e-government in the Federal Government of Nigeria. This topic was chosen because e-governance serves as an alternative means of providing public services rather than depending on the old bureaucratic methods of public goods and service delivery. The paper uses data derived from questionnaire administered to 3,000 Federal Government employees and various stakeholders of the government in Abuja, the federal capital, Lagos and some state capitals in the country. An in-depth one-to-one interview of 300 relevant federal government agencies' officials were also conducted. The participants of the survey and interviews respectively included stakeholders such as traders, vendors of federal government's ministries and agencies, NGO staff, lawyers, law enforcement officers, teachers, farmers, taxi drivers, housewives, unemployed graduates, youth corps members, private business leaders, political leaders, nurses, soldiers, local communities, and suppliers and distributors. The secondary data consisted of the review of related government reports in 
Nigeria, government websites, academic and professional journals. Data were analyzed to determine the impacts of e-governance in the national government. The research was conducted between 2016 and 2018 in Nigeria. A total of 2,025 (63.2\%) questionnaire was completed and returned by the respondents. A cross sectional time-span was used, and all data collection and analysis performed in a quantitative and qualitative manner. Data collected were also analyzed with SPSS statistical tool and presented in correlations, frequency tables and percentile. The paper also used Likert scale of 5: 1=strongly disagree' to 5=strongly agree. According to Asmi at al. (2017), and Saunders et al. (2009) Likert scale is one of the best instrument to use when studying human social perception, behavior and attitude.

Interviews were conducted among the same federal ministries and agencies that the questionnaire were administered. A random sample of individuals from the list of non-governmental stakeholders provided above were also interviewed. The central research questions are: (1) Do you think the federal government of Nigeria is using many forms of e-governance to deliver services to the citizens? (2) Do you believe that the federal government of Nigeria is delivering services efficiently to citizens because of the introduction of e-government initiatives? (3) What do you consider to be the barriers to e-government in Nigeria.? (4) Do you notice any improvement in the citizens and federal government relationship because of e-government in the past 10 years?

The limitation of the study is that only a random sample of 2,325 out of the more than 50,000 Federal Government of Nigeria employee were covered by this research. In addition, state and local government ministries and agencies were not included in the respondents' sample. The dependent variable is e-governance, and the independent are forms of e-governments platform used, efficiency of services delivery as a result of e-governance, barriers of e-government, and the nature of citizen and government relations as a result of e-governance in Nigeria.

\section{Analysis of E-Government Data and Discussion}

The demography of the respondents for this research include 2,025 (questionnaires) and 300 (interviewed) stakeholders of the federal governments public service, business executives, doctors, lawyers, law enforcement officers, teachers, housewives, traders, farmers, nurses and. administrators of nongovernmental organizations. Further, 1,150 respondents were men and the remaining 1,225 were women. Table 1 to 6 are utilized to analyze the respondents' response to the four research questions.

Research Question 1:

Do you think the Federal Government of Nigeria is using many forms of e-governance to deliver services to the citizens?

Table 1 shows how the Federal Government of Nigeria is using e-government to provide public services to citizens within and outside the country. Questionnaire items 6 to 16 were utilized in the analysis of the type of services that the Federal Government of Nigeria have been using e-government to provide. Table 1 reveals that of $66 \%$ of the listed e-government platforms were effectively used by the government. The questionnaire respondents indicated that most 
effective e-government platforms are websites $(86.5 \%)$, the use of IT to pay bills $(84.7 \%)$, citizens' access to checking government database online $(83.3 \%)$, government staff use of email to communicate with citizens $(81.6 \%)$ and Federal governments ministries have email address (76\%). Table 1 also show that $34 \%$ of the questionnaire respondents however indicated that digital democracy through electronic voter registration, public opinion polling, and communication among elected representative and citizens of their respective constituencies are not yet available in Nigeria. Only $87 \%$ percent of the respondents stated that they could receive email from their boss about work related issues. It is interesting to note that $57.5 \%$ indicated that they still cannot use the internet platform to access government services without going to the federal government offices or contacting their staff by telephone.

Another $57.5 \%$ of the questionnaire respondents stated that they could not apply for Federal Government jobs online or by filling out application online. Most Federal Government ministries only post information on their websites directing interested job applicants to make payments to a specified commercial Bank account as well as collect government application forms from the bank. Applicants are also required to submit their application and curriculum vitae with the payment receipt or teller to the ministry's office in person.

Table 1. Federal Government is using many forms of E-Governance to deliver services.

\begin{tabular}{|c|c|c|c|c|c|c|c|c|}
\hline Questions & $\begin{array}{l}\text { Strongly } \\
\text { Disagree }\end{array}$ & Disagree & Agree & $\begin{array}{l}\text { Strongly } \\
\text { Agree }\end{array}$ & Neutral & $\underset{\%}{\text { Agree }}$ & $\begin{array}{c}\text { Disagree } \\
\%\end{array}$ & $\begin{array}{l}\text { Total } \\
2025\end{array}$ \\
\hline $\begin{array}{l}\text { My office has an official } \\
\text { email address. }\end{array}$ & 229 & 243 & 533 & 991 & 29 & $\begin{array}{l}1524 \\
76 \%\end{array}$ & $\begin{array}{l}472 \\
\mathbf{2 6 \%}\end{array}$ & 1,996 \\
\hline $\begin{array}{l}\text { All employees are } \\
\text { expected to have official } \\
\text { email address. }\end{array}$ & 138 & 234 & 649 & 1004 & 0 & $\begin{array}{l}1653 \\
\mathbf{8 1 . 6 \%} \\
\end{array}$ & $\begin{array}{l}372 \\
\mathbf{1 8 . 4 \%} \\
\end{array}$ & 2,025 \\
\hline $\begin{array}{l}\text { My office has a website } \\
\text { address. }\end{array}$ & 173 & 100 & 549 & 1201 & 2 & $\begin{array}{l}1750 \\
\mathbf{8 6 . 5 \%}\end{array}$ & $\begin{array}{ll}273 \\
13.5 \%\end{array}$ & 2,023 \\
\hline $\begin{array}{l}\text { My boss frequently sends } \\
\text { me email. }\end{array}$ & 765 & 998 & 154 & 108 & 0 & $\begin{array}{ll}262 \\
12.9 \%\end{array}$ & $\begin{array}{l}1763 \\
\mathbf{8 7 . 1 \%}\end{array}$ & 2,025 \\
\hline $\begin{array}{l}\text { Govt. Staff can receive } \\
\text { email from citizens } \\
\text { seeking information }\end{array}$ & 374 & 527 & 668 & 450 & 6 & $\begin{array}{l}1118 \\
\mathbf{5 5 . 4 \%} \\
\end{array}$ & $\begin{array}{l}901 \\
\mathbf{4 4 . 6 \%} \\
\end{array}$ & 2,019 \\
\hline $\begin{array}{l}\text { Citizens can apply for jobs } \\
\text { via online application }\end{array}$ & 676 & 488 & 553 & 308 & 0 & $\begin{array}{l}861 \\
\mathbf{4 2 . 5 \%} \\
\end{array}$ & $\begin{array}{l}1164 \\
\mathbf{5 7 . 5 \%} \\
\end{array}$ & 2,025 \\
\hline $\begin{array}{l}\text { Citizen pay utilities bills } \\
\text { on-line }\end{array}$ & 157 & 173 & 984 & 708 & 3 & $\begin{array}{l}1692 \\
84.7 \%\end{array}$ & $\begin{array}{ll}330 \\
\mathbf{1 6 . 3 \%}\end{array}$ & 2,022 \\
\hline $\begin{array}{lcc}\text { Citizens can } & \text { file } \\
\text { complaints on-line } & \\
\end{array}$ & 66 & 595 & 769 & 595 & 0 & $\begin{array}{l}1364 \\
67.4 \%\end{array}$ & $\begin{array}{l}661 \\
32.6 \%\end{array}$ & 2,025 \\
\hline $\begin{array}{l}\text { Citizens can search govt. } \\
\text { databases online }\end{array}$ & 60 & 277 & 1286 & 396 & 6 & $\begin{array}{l}1682 \\
\mathbf{8 3 . 3 \%} \\
\end{array}$ & $\begin{array}{l}337 \\
16.7 \% \\
\end{array}$ & 2,019 \\
\hline $\begin{array}{l}\text { Govt. use technology for } \\
\text { education, and improve } \\
\text { neighborhood safety }\end{array}$ & 150 & 471 & 886 & 510 & 8 & $\begin{array}{l}1396 \\
\mathbf{6 9 . 2 \%} \\
\end{array}$ & $\begin{array}{l}621 \\
\mathbf{3 0 . 8 \%} \\
\end{array}$ & 2,017 \\
\hline
\end{tabular}

Source: Derived from Field research in Nigeria in 2016 and 2018.

In addition, among the 300 interview respondents 166 (55\%) stated that the Federal Government of Nigeria is now using various platforms of e-government to enhance efficiency, 
productivity and service delivery in country. Despite the e-government initiatives of the government another $55 \%$ of the respondents indicated that some federal government ministries and agencies are lacking the necessary technology, infrastructure and human capital to effectively implement the e-government initiatives. Generally, all the respondents also indicated that some leaders in the Federal Government of Nigeria do not understand the relationship between e-government, effective delivery of service and governance. Such leaders prefer to perform their duties the traditional way instead of using technology that are readily available. Below are some statements made by respondents during the interview section:

"E-government is a good initiative however the Nigerian Federal Government has not yet trained many of its public administrators to attain sufficient information technology skills."

"The amount of funding and equipment that has been provided to my ministry makes me to feel that the Federal Government of Nigeria is not seriously committed to the effectiveness of e-government. It is all about slip service and nothing to show for it

"All we tell the citizens when they come to seek services in our ministry is that the server has gone down. On the other hand, the government has not done anything to improve the performers of the broadband, modem, and electronic server. Leaders that supposed to help public administers to get the best server or broadband tend to blame technology and electricity for poor service delivery to citizens."

\section{Research Question 2:}

Do you believe that the Federal Government of Nigeria is delivering services efficiently to citizens because of the introduction of the e-government initiatives?

Table 2. Government of Nigeria is delivering services efficiently through E-Government

\begin{tabular}{|c|c|c|c|c|c|c|c|c|}
\hline Questions & $\begin{array}{l}\text { Strongly } \\
\text { Disagree }\end{array}$ & Disagree & Agree & $\begin{array}{c}\text { Strongly } \\
\text { Agree }\end{array}$ & Neutral & Agree & Disagree & $\begin{array}{l}\text { Total } \\
\mathbf{2 , 0 2 5} \\
\end{array}$ \\
\hline $\begin{array}{l}\text { Govt. use technology } \\
\text { effectively to enhance } \\
\text { access to public service } \\
\end{array}$ & 129 & 371 & 886 & 610 & 29 & $\begin{array}{l}1496 \\
\mathbf{7 5 \%}\end{array}$ & $\begin{array}{r}500 \\
\mathbf{2 5 \%}\end{array}$ & 1996 \\
\hline $\begin{array}{c}\text { Citizens' deliberations are } \\
\text { conducted through digital } \\
\text { town hall meetings. }\end{array}$ & 543 & 692 & 415 & 255 & 120 & $\begin{array}{r}670 \\
\mathbf{3 5 \%}\end{array}$ & $\begin{array}{l}1235 \\
\mathbf{6 5 \%}\end{array}$ & $1905 *$ \\
\hline $\begin{array}{c}\text { Govt. has effectively } \\
\text { implemented technology } \\
\text { innovation. }\end{array}$ & 637 & 436 & 488 & 394 & 68 & $\begin{array}{c}882 \\
\mathbf{4 5 \%}\end{array}$ & $\begin{array}{l}1075 \\
\mathbf{5 5 \%}\end{array}$ & $1957 *$ \\
\hline $\begin{array}{l}\text { Citizens can apply for } \\
\text { govt. permit or licenses } \\
\text { on-line. }\end{array}$ & 527 & 707 & 488 & 386 & 17 & $\begin{array}{c}774 \\
\mathbf{3 9 \%}\end{array}$ & $\begin{array}{l}1234 \\
\mathbf{6 1 \%}\end{array}$ & $2,008 *$ \\
\hline $\begin{array}{l}\text { Policies and regulations } \\
\text { are available in our } \\
\text { website. }\end{array}$ & 243 & 179 & 694 & 589 & 320 & $\begin{array}{l}1283 \\
\mathbf{7 5 \%}\end{array}$ & $\begin{array}{c}422 \\
25 \%\end{array}$ & 1705 \\
\hline $\begin{array}{l}\text { Emails are accepted as } \\
\text { official methods of } \\
\text { communication. }\end{array}$ & 638 & 471 & 486 & 310 & 8 & $\begin{array}{c}796 \\
\mathbf{4 2 \%}\end{array}$ & $\begin{array}{l}1109 \\
\mathbf{5 8 \%}\end{array}$ & $1905^{*}$ \\
\hline
\end{tabular}


Source: Derived from Field research in Nigeria in 2016 and 2018.

Table 2 shows that $52 \%$ of the questionnaire respondents indicated that the Federal Government of Nigeria is using e-government to deliver services efficiently. On the other hand,48\% of the respondents stated that many federal government administrators have not effectively use technology to enhance public service delivery. The most notable consensus of this group is that citizens deliberations are not yet conducted through digital town hall meetings (65\%), and citizens still cannot apply for government permit or licenses online $(61 \%)$. It was also indicated by respondents that low literacy of some citizens and the inability to use computers are major constraints that make some citizens to attest that e-government has not improve government service delivery that much in the country.

In addition, $65 \%$ of the interviewed respondents stated that they believe e-government has positively enhance government service delivery in some areas. This group contend that the ability of e-government to create access for citizens in respective of their location around the world makes the initiative one of the best provided by the Federal Government of Nigeria. Further, $35 \%$ of the interview respondents indicated that e-government has not help to provide efficient service delivery in the country. This is because the type of services provided by the Nigerian e-government portal could be considered as only "one-way service delivery." The citizens can only get information from the e-government portal but are not able to respond and get feedback. Below are some statements made by the interview respondents:

"I believe that the lack of cooperation among federal government ministries and agencies greatly constitute a major impediment to the development and implementation of e-government in Nigeria."

"Rather than creating a national priority, the differences and commitment of various ministries have negatively affected the development of e-government in Nigeria."

"In my ministry some senior public administrators do not like to use e-government in the delivery of service. They tend to believe that a wider usage of internet might decrease their function in the future, and so e-government is a threat."

Table 3. Correlation Matrix for use of E-Government for Service Delivery and Efficiency

\begin{tabular}{c|c|c|c}
\hline Factors & Index & $\begin{array}{c}\text { Average Agree } \\
\text { Factors } \\
\%\end{array}$ & $\begin{array}{c}\text { Average Disagree } \\
\text { Factors } \\
\%\end{array}$ \\
\hline Use of E-Government for Service Delivery & $0.089 *$ & $66 \%$ & $34 \%$ \\
\hline E-Government and Service Efficiency & 0.037 & $52 \%$ & $48 \%$ \\
\hline
\end{tabular}

*Correlation is significant at the 0.05 level (2-tailed)

Table 3 shows the strong correlation of (0.089) for the use of e-government to deliver service to stakeholders by Federal Government of Nigeria. There is however a weak relationship between e-government and efficient service delivery in most ministries and agencies in the 
Federal government of Nigeria. It is also interesting to note that the average agreed factors are $66 \%$ for use of e-government for service delivery, and $34 \%$ average disagree factors for the same item. Further, while the average agreed factors are $52 \%$ for e-government and service efficiency, the average disagree factor is $48 \%$. These finding are consistent with the outcome of the research previously performed by Olufemi (2012) and Ashaye (2014) that the real problem facing the emergence of e-governance in Nigeria. On one hand, e-governments have their roots based on socioeconomic status, computer skills, and inadequate infrastructure in Nigeria. On the other hand, the e-governance impediments also lie in poor organizational skills.

Research Question 3:

What do you consider to be the barriers to e-government in Nigeria.?

Table 4. Barriers to e-government in Nigeria.

\begin{tabular}{|c|c|c|c|c|c|c|c|c|}
\hline Barriers & $\begin{array}{l}\text { Strongly } \\
\text { Disagree }\end{array}$ & Disagree & Agree & $\begin{array}{l}\text { Strongly } \\
\text { Agree }\end{array}$ & Neutral & $\underset{\%}{\text { Agree }}$ & $\begin{array}{c}\text { Disagree } \\
\%\end{array}$ & Total \\
\hline Electricity & 115 & 267 & 986 & 657 & 0 & $\begin{array}{l}1643 \\
\mathbf{8 1 \%}\end{array}$ & $\begin{array}{c}382 \\
18 \%\end{array}$ & $2,025^{*}$ \\
\hline $\begin{array}{l}\text { High Frequent of bad } \\
\text { network }\end{array}$ & 129 & 109 & 837 & 872 & 39 & $\begin{array}{l}1709 \\
\mathbf{8 6 \%}\end{array}$ & $\begin{array}{c}277 \\
14 \%\end{array}$ & $1986^{*}$ \\
\hline $\begin{array}{l}\text { No network in rural } \\
\text { areas }\end{array}$ & 181 & 289 & 699 & 848 & 8 & $\begin{array}{l}1547 \\
\mathbf{7 7 \%}\end{array}$ & $\begin{array}{l}470 \\
23 \%\end{array}$ & $2,014 *$ \\
\hline $\begin{array}{l}\text { Lack of technology or } \\
\text { web staff in house }\end{array}$ & 781 & 643 & 342 & 259 & 0 & $\begin{array}{c}601 \\
\mathbf{3 0 \%}\end{array}$ & $\begin{array}{l}1424 \\
70 \%\end{array}$ & 2,025 \\
\hline $\begin{array}{l}\text { ICT infrastructure: } \\
\text { E-readiness, computer } \\
\text { literacy, }\end{array}$ & 153 & 198 & 901 & 773 & 0 & $\begin{array}{l}1674 \\
\mathbf{7 0 \%}\end{array}$ & $\begin{array}{c}351 \\
30 \%\end{array}$ & $2,025^{*}$ \\
\hline $\begin{array}{l}\text { Lack of financial } \\
\text { resources }\end{array}$ & 263 & 224 & 683 & 844 & 11 & $\begin{array}{l}1521 \\
\mathbf{7 6 \%}\end{array}$ & $\begin{array}{l}487 \\
\mathbf{2 4 \%}\end{array}$ & $2,014 *$ \\
\hline Old IT equipment & 209 & 391 & 697 & 683 & 45 & $\begin{array}{l}1380 \\
\mathbf{7 0 \%}\end{array}$ & $\begin{array}{l}600 \\
30 \%\end{array}$ & $1980^{*}$ \\
\hline $\begin{array}{lr}\text { Lack of e-policy } \\
\text { enforcement } & \text { and } \\
\text { implementation } & \end{array}$ & 176 & 144 & 865 & 832 & 8 & $\begin{array}{l}1697 \\
\mathbf{8 4 \%}\end{array}$ & $\begin{array}{r}320 \\
16 \%\end{array}$ & $2,017 *$ \\
\hline Corruption & 50 & 28 & 1026 & 921 & 0 & $\begin{array}{l}1947 \\
\mathbf{9 6 \%} \\
\end{array}$ & $\begin{array}{r}78 \\
\mathbf{4 \%} \\
\end{array}$ & $2,025^{*}$ \\
\hline Resistance to change & 135 & 165 & 811 & 903 & 11 & $\begin{array}{l}1714 \\
\mathbf{8 5 \%} \\
\end{array}$ & $\begin{array}{r}300 \\
15 \% \\
\end{array}$ & $2,014 *$ \\
\hline $\begin{array}{l}\text { Public, private and } \\
\text { community } \\
\text { partnership, network }\end{array}$ & 903 & 594 & 200 & 328 & 27 & $\begin{array}{c}528 \\
26 \%\end{array}$ & $\begin{array}{l}1470 \\
74 \%\end{array}$ & 1998 \\
\hline $\begin{array}{l}\text { Lack of Strategic } \\
\text { Vision of Govt. }\end{array}$ & 147 & 293 & 693 & 889 & 3 & $\begin{array}{l}1582 \\
\mathbf{7 8 \%}\end{array}$ & $\begin{array}{r}440 \\
\mathbf{2 2 \%}\end{array}$ & $2,022 *$ \\
\hline
\end{tabular}

Source: Derived from Field research in Nigeria 2016-2018.

Table 4 shows that $72 \%$ the questionnaire respondents indicated that some of the barriers to e-government at the federal government level include electricity (81\%), lack of e-policy enforcement and implementation (96\%), resistance to change (85\%) and lack of strategic vision $(78 \%)$. The respondents who disagreed that these barriers do not exist in the country constitute only $28 \%$. This group believe that public, private and community partnership 
network are not visible barriers to e-government in Nigeria. There is a consensus among all respondents however that e-government activities in Nigeria are still very low. As at the time of writing this paper in 2018, apart from the bank verification number (BVN), national identification number, national driving license, and immigration entry and exit information the Federal Government of Nigeria do not have any other established database.

On the other hand, $61 \%$ of the interview respondents agree that the barriers listed in table 3 exist in the country. These respondents indicated that corruption (91\%) and high frequency of bad network (86\%) were the major barriers to e-government in Nigeria. In addition, 39\% of the interview respondents disagree that the listed barriers were not major impediments to e-government in Nigeria. A total of $61 \%$ of the interview respondents unanimously agreed that the lack of information technology in the curricula at all levels education in Nigeria is the major impediment to effective e-government in the country. All the respondents indicated that social media is becoming more effective than e-government in Nigeria. Although progress toward the effective implementation of the e-government initiatives are very slow, the Federal Government of Nigeria tend to be moving in the right direction towards achieving its goals on e-government.

Research Question 4:

Do you notice any improvement in the citizens and federal government relationship because of e-government in the past 10 years?

Table 5 shows that of $23 \%$ of the questionnaire respondents indicated that e-government has galvanized a major improvement in citizens and government relations in Nigeria since 2001 when the policy was enacted. The respondents stated that although e-government is not fully functional in Nigeria, they agree that digital governance will have a positive impact on the federal government of Nigeria in the future as well as citizens relationship with the government. On the other hand, $77 \%$ disagree that e-government has led to any major improvement in the relationship between citizens and the federal government. It is very interesting to note that $80 \%$ of the respondents that are public administrators disagreed that there has been any major improvement between government and the citizens relations due to e-government. Farmers (92\%) and traders (88\%) also disagree as well respectively.

The interview data shows that $81 \%$ of respondents indicated that e-government has not help to build nor improve citizens and government relations in Nigeria. Only $19 \%$ of the interview respondents agree that e-government has improved citizens and government relations in the country. Below are some statements made by respondents

"Although it has been argued that e-government strengthens democratic processes, accountability and transparency, reduce corruption and enhanced governance, the situation in Nigeria is such that government red-tape is the biggest impediment to improving citizens and government relations in the country."

"I believe that the more Nigerian citizens use government websites, the more satisfy they are likely going to be with e-government. Such citizen satisfaction 
is likely going to increase their trust in government in the future."

"Despite the fact that I think e-government has made it convenient for me to conduct transaction with government, I still believe that a reduction of red-tape might improve customer service as well as communication between government and citizens."

Table 5. Improvement in citizens and Federal Government Relationship

\begin{tabular}{l|c|c|c|c|c|c|c|c}
\hline $\begin{array}{l}\text { Profile } \\
\text { Respondents }\end{array}$ & $\begin{array}{c}\text { Strongly } \\
\text { Disagree }\end{array}$ & Disagree & Agree & $\begin{array}{c}\text { Strongly } \\
\text { Agree }\end{array}$ & Neutral & $\begin{array}{c}\text { Agree } \\
\mathbf{\%}\end{array}$ & $\begin{array}{c}\text { Disagree } \\
\mathbf{\%}\end{array}$ & $\begin{array}{c}\text { Total } \\
\mathbf{2 0 2 5}\end{array}$ \\
\hline Public Servants & 688 & 927 & 210 & 200 & 0 & $\begin{array}{c}410 \\
\mathbf{2 0 \%}\end{array}$ & $\begin{array}{c}1615 \\
\mathbf{8 0 \%}\end{array}$ & 2,025 \\
\hline $\begin{array}{l}\text { Business } \\
\text { Executives }\end{array}$ & 267 & 333 & 596 & 823 & 6 & $\begin{array}{c}1419 \\
\mathbf{7 0 \%}\end{array}$ & $\begin{array}{c}600 \\
\mathbf{3 0 \%}\end{array}$ & $2,019 *$ \\
\hline Farmers & 1031 & 825 & 103 & 57 & 4 & $\begin{array}{c}160 \\
\mathbf{8 \%}\end{array}$ & $\begin{array}{c}1856 \\
\mathbf{9 2 \%}\end{array}$ & 2,016 \\
\hline Housewives & 944 & 766 & 63 & 147 & 4 & $\begin{array}{c}310 \\
\mathbf{1 5 \%}\end{array}$ & $\begin{array}{c}1712 \\
\mathbf{8 5 \%}\end{array}$ & 2,022 \\
\hline $\begin{array}{l}\text { Law Enforcement } \\
\text { Officers }\end{array}$ & 1001 & 588 & 231 & 199 & 6 & $\begin{array}{c}430 \\
\mathbf{2 1 \%}\end{array}$ & $\begin{array}{c}1589 \\
\mathbf{7 6 \%}\end{array}$ & 2,019 \\
\hline Lawyers & 899 & 649 & 202 & 275 & 0 & $\begin{array}{c}477 \\
\mathbf{2 4 \%}\end{array}$ & $\begin{array}{c}1548 \\
\mathbf{7 6 \%}\end{array}$ & 2,025 \\
\hline Medical Doctors & 921 & 677 & 209 & 211 & 7 & $\begin{array}{c}420 \\
\mathbf{2 1 \%}\end{array}$ & $\begin{array}{c}1598 \\
\mathbf{7 9 \%}\end{array}$ & 2,018 \\
\hline NGO Staff & 866 & 911 & 156 & 84 & 8 & $\begin{array}{c}240 \\
\mathbf{1 2 \%}\end{array}$ & $\begin{array}{c}1777 \\
\mathbf{8 8 \%}\end{array}$ & 2,017 \\
\hline Teachers & 984 & 593 & 300 & 139 & 8 & $\begin{array}{c}439 \\
\mathbf{2 2 \%}\end{array}$ & $\begin{array}{l}1577 \\
\mathbf{7 8 \%}\end{array}$ & 2,017 \\
\hline Traders & 1120 & 671 & 200 & 34 & 0 & $\begin{array}{c}234 \\
\mathbf{1 2 \%}\end{array}$ & $\begin{array}{l}1791 \\
\mathbf{8 8 \%}\end{array}$ & 2,025 \\
\hline
\end{tabular}

Source: Derived from Field research in Nigeria in 2016 and 2018.

Table 6 shows the negative relationship between barriers to e-government (0.037) and improved citizens and government relations (0.031). In addition, the average agree factor for barriers to e-government was $72 \%$ compared to the average disagree factors of $28 \%$. In respect of improve citizens and government relations the average agreed factor was $23 \%$, while the average disagreed factors were $77 \%$. The data reveals that citizens distrust in the ability of government to effectively deliver services as well as been transparent. The federal government has not done much to motivate stakeholders in building a better citizen and government relationship. As a result of the federal government not been transparent and accountable to the citizens of Nigeria, the people of the country have decided to distance themselves from the government. Therefore, it could be argued that the e-government initiative has not yet promoted a better democracy and good governance system in Nigeria after almost two decades when the policy was enacted.

In addition to the questionnaire results $70 \%$ of the interview respondents indicated that e-government has not help to improve citizens and government relations in Nigeria. Another $30 \%$ however agreed that there are some elements of improvement in citizen-government partnership. Disparities in government processes, unnecessary cost to citizens, waist of time due to red-tape bureaucracies, and corruption are some of the major constraints that has 
prevented a more robust citizens and government relations in Nigeria. About $98 \%$ of the interview respondents stated that they wish the federal government of Nigeria could improve the resources available to citizens so that federal ministries and agencies could efficiently deliver services on time.

Table 6. Correlation Matrix for Barrier to E-Government and Citizens and Government Relations

\begin{tabular}{c|c|c|c}
\hline Factors & Index & $\begin{array}{c}\text { Average Agree } \\
\text { Factors } \\
\mathbf{\%}\end{array}$ & $\begin{array}{c}\text { Average Disagree } \\
\mathbf{\%}\end{array}$ \\
\hline Barriers to E-Government & 0.042 & $72.4 \%$ & $28 \%$ \\
\hline $\begin{array}{c}\text { Improved Citizens and Government } \\
\text { Relations }\end{array}$ & 0.031 & $23 \%$ & $77 \%$ \\
\hline
\end{tabular}

*Correlation is significant at the 0.05 level (2-tailed)

In general, e-government is gradually moving away from a technology that primarily provides information in Nigeria to the transaction stage, or the interactive provision of public services to citizens. The 2001 Nigerian Informational Technology policy has added impetus to the goals of connecting communities, citizens, ministries, government agencies, institutions of government and educational institutions at all levels with information, communication and technology (Olufemi 2012; Ajibade et al 2017). There is no doubt that e-government is perceived to be experiencing major challenges in its implementation in Nigeria. This impediment is due to the amount of expertise and personnel required for its successful development. This notwithstanding, because it is paramount for public administrators to be educated about the importance and benefits of adopting e-governance in the administration and their bid to build a more robust relationship and trust with citizens.

\section{Public Policy Recommendations}

The public management perspective on e-government has been to transform service delivery by fully utilizing information communication and technology. This perspective of e-governance entails a framework of electronic administration, electronic citizens, electronic commerce, electronic service and electronic communities. (Henry 2013, Olufemi 2012; Ajibade et al 2017). Despite these electronic and interactive frameworks, the Federal Government of Nigeria has not been fully able to interact with business, citizens, state and local governments through electronic medium such as websites, emails, voice systems instead of the traditional person to person and paper transaction. Other challenges include lack of systems integration within a department, lack of integration across government departments, limited knowledge of using computers at various levels of bureaucracy and deployment of technology without proper process, re-engineering, and lack of constant electricity. These challenges have not enable the country to cross the boundary between the physical and the digital technology systems by becoming involved in the virtual electronic world (Nkwe 2012; Dawes 2010).

As a result of the current state of e-government in Nigeria, the authors of this paper would like to propose the following recommendations as a way forward: In order to ensure a better 
e-government system in the country, it is recommended that an appropriate legislation for a comprehensive e-government law to be enacted in Nigeria with all relevant guidance for its implementation. The new e-government policy should mandate integrating public participation and shared governance in the democracy of the nation. This law must also harmonize the roles and responsibilities of the different ministries involved in the e-government, which has been a big source of confusion and duplicity.

In addition, once enacted, the new e-government law should be effectively implemented. Enactment of policies without implementation amounts to confusion. Also lack of continuity of public policy after a regime change has created a forum for lack of stable social and economic development in Nigeria (Dibie 2018; Agunloye 2007). The policy should also provide the state and local governments with clear authority and adequate funding to meet up with the growing needs of e-government. It should also make provision for public-private-partnerships in e-governance. This new initiative could create employment opportunities and more jobs for stakeholders all over the country. Improving e-government depends so much on the institutions of government as well as the right technologies (Muhammed et al 2010; Mahapatra \& Perumal 2004). It is therefore important to consolidate e-government functions between federal and state government on one hand, and federal and local governments on the other hand. This is how e-government could create positive impact on the federalism system of government in Nigeria. This could also enhance public management, financial transparency and accountability. Collaboration of all stakeholder may also increase citizens and government relationship in Nigeria.

The Federal Government of Nigeria should make it mandatory for education curricular at all levels to train students how to use computers and the internet that are common in the public and private sectors in the country. In addition to this recommendation for computer usage training in schools all over the country. There is also the need for the government to hire professional information technology staff in all its ministries and agencies. These information technology experts should also conduct internal computer staff training for all employees. A computer user-friendly services environment should be created. Although, there is a proliferation of smart phones, social media and an expansion of broadband communication networks in Nigeria. The internet penetration is growing at a faster rate while disposable income of the public is not growing as expected. At the same time, households with PCs are also growing faster in the urban areas when compared to the rural regions in the country (Ajibade, et al 2017; Babalola 2013; Adeyemo 2011).

There is the need for the Federal Government of Nigeria to do more to provide electricity supply in both urban and rural areas in the country. Constant electricity supply could also lead to better functioning broadband and wider coverage in Nigeria. The government also need to embark on creating awareness of the important of their services through e-government initiatives. A conductive political, economic and social environment needs to be developed for the effective implementation of e-government in Nigeria. Further, the need to respond to customer needs, and government policies are some of the factors that could create a better political climate for e-government to become the order of the day (Nwawenda \& Al Mazari, 2012). The Federal Government of Nigeria must seriously address the nation's current 
barriers to effective information technology service delivery system before it can achieve a better e-governance and democratic system.

\section{Conclusion}

This paper has examined the nature and effectiveness of e-government in the Federal Government of Nigeria. It argues that the utilization of technologies such as internet, websites, email and social media have not effectively open the door for more integrated technological efforts to connect citizens, and the government. In addition, the federal government of Nigeria has not fully adopted the new e-government approaches to improve its services. The paper explored how information communication and technology (ICT) policy of Nigeria has galvanized the government to address the way in which information is gathered, protected, used, and shared. It also analyzed how e-government has enhanced public service delivery and quality as well improve citizens and government relations in the country. It addresses the question: to what extent has the evolution of e-government in Nigeria contributed to cost-effectiveness in the federal government operations and the way citizens engage in the democratic process in the country.

The research findings of this paper reveal that although the Federal Government of Nigeria has introduced many e-government initiatives for stakeholders to have access to public services, the desired outcomes are not yet fully achieved in the country. Interview respondents indicated that the government has not been able to effectively interact with citizens, business, and other governments as initially expected. To a large extent the federal government official has somewhat improved their communication through personal cellphones and text messages rather than emails, websites and interactive voice systems than in person or on paper. In addition, despite the goal for e-government to provide a faster, transformational services, and a better life for all stakeholders many federal government ministries, department and agencies have not fully established their websites. These major challenges have also prevented the Federal Government of Nigerian to effectively link citizens to information about government processes, programs, services opportunities, events, online neighborhood communities, job advertisement and e-application.

One of the key findings of this paper is that the Federal Government of Nigeria is still plagued with the problem of deficiencies of bureaucracy. The interest of the federal ministries and agencies are mostly vested internally instead of externally to the stakeholders and citizens. The only legitimate solution is to re-invigorate e-government in such a way as to enhance service delivery, and a better relationship between citizen and government. In addition, the federal government should require all its employees to be competent in the use of technology as well as using e-government as the main mechanism of providing both citizens and businesses public services.

The research for this paper also found that although, the federal government has appropriated several billion dollars budget for the purchase of new technology equipment, there are many offices that do not have computers or electricity. It is apparent that budget restrictions and corruption has made it difficult for some jurisdiction to develop and maintain website, and technology-related services. Other challenges observed include ethical implications, such as 
ensuring broad-based access, and the management of electronic records of citizens and archives on fast running computer system. Some of the problems includes, security concern for the citizen, redefining rules and procedures, information transparency, legal issues, infrastructure, skill and awareness, access to right information, new computers, inter-departmental collaboration, and the tendency to resist the change in work culture., These challenges have led to a very low relationship between citizens and public agencies using e-government in Nigeria.

Therefore, the leaders of the federal government of Nigeria must seek new and improved ways of providing efficient, effective, and citizen friendly e-government information and services to all their stakeholders. Instead of depending on the traditional one-way information communication technology model, what the Federal Government of Nigeria need is a conscious effort to create appropriate e-government policies and procedures that could bring citizens together. Such shared governance initiative could encourage and enable citizens and other stakeholders to become actively engaged in the process of finding lasting solutions to the democratic system in the country. The limitation of this paper is that it covers only the federal government of Nigeria. Future research on e-government in state and local government in Nigeria may use a more robust approach in analyzing e-commerce, e-readiness, e-government, the e-quality and their relationship with all stakeholders in the country.

\section{References}

Abdallah, S., \& Fan, I. S. (2012). Framework for e-government assessment in developing countries: case study from Sudan. Electronic Government, an International Journal, 9(2), 158-177. https://doi.org/10.1504/EG.2012.046267

Adeyemo, A. B. (2011). E-government implementation in Nigeria: an assessment of Nigeria's global e-gov ranking, Journal of Internet and Information System, 2, 11- 19.

Agunloye, O. (2007). An overview of the implementation of e-government program in Nigeria. First international conference on theory and practice of electronic governance, ICEGOV, Macao, China. 10 - 13 December 2007. https://doi.org/10.1145/1328057.1328060

Ajibade, O., Ibietan, J., \& Ayelabola, O. (2017). E - governance implementation and public service delivery in Nigeria: The technology acceptance model (TAM) application. Journal of Public Administration and Governance, 7(4), 1-10. https://doi.org/10.5296/jpag.v7i4.11475

Ashaye, O. O. R. (2014). Evaluating the implementation of e-government in developing countries: The case of Nigeria. Ph.D. dissertation Brunel business school, Brunel University, London, England.

Asmi, F., Zhou, R., \& Liu, L. L. (2017). E-government adoption in developing countries: need of customer-centric approach: A case of Pakistan. International Business Research, 10(1), 42-58. https://doi.org/10.5539/ibr.v10n1p42

Babalola, Y. T. (2013) Nigeria's information infrastructure policy: implications for e-government in Arabian Journal of Business and Management Review, 2(11), 8-15. 
Bhatnagar, S. C., \& Nupur, S. N. (2010). Assessing the impact of e-government: A study of projects in India. Information Technologies \& International Development, 6(2), (Summer). $109-127$.

Bwalya, K. J. (2017). Determining factors influencing e-government development in the developing world: A case study of Zambia. Journal of E-Government Studies and Best Practices, 1, 16-31.

Calista, D. J., \& Melitski, J. (2007). E-government and e-governance: converging constructs of public sector Information and Communications Technologies. Public Administration Quarterly, 32(1), 10-12.

Cloete, F. (2003). Assessing governance with electronic policy management tools. Public Performance and Management Review, 26(3), 276-290. https://doi.org/10.1177/1530957602250233

Coates, B. E. (2001-2002). Smart government online, not inline. The public manager, 30(4), (Winter), 1-5.

Congressional Research Service. (2003). A primer on e-government: sector, stages, opportunities and challenges of online government. www.fas.org/sgp/crs/RL31057.pdf. Accessed April 23, 2018.

Dawes, S. (2010). The evolution and continuing challenges of e-government. Public Administration Review 70, Supplement 1 (December), 86-102.

Denhardt, R., Denhardt, J., \& Blanc, T. (2014). Public administration: an action orientation. Boston, MA: Wadsworth/ Cengage Learning

Dibie, R. (2014). Public administration: analysis, theories and application. Ilishan Remo, Ogun State, Nigeria: Babcock University Press.

Dibie, R. (2018). Business and government relations in Africa. New York: Taylor and Francis/Routledge Press.

Dibie, R., Edoho, F. M., \& Dibie, J. (2015). Analysis of capacity building and sustainable development in Africa. Journal of Business and Social Science, 12(2), 1-23.

Dibie, R., Edoho, F. M., \& Dibie, J. (2018). Business and government partnership in Nigeria. In Business and Government Relations in Africa, edited by Robert Dibie. New York: Routledge Press.

Dode, R. O. (2007). Prospects of e-government implementation in Nigeria. ICEGOV 2007, Macao, 10-13 December 2007. https://doi.org/10.1145/1328057.1328137

Fang, Z. (2002). E-government in digital era: concept, practice and development. International Journal of the Computer, 10(2), 1-22.

Freeman, R. E. (1984). Strategic management: a stakeholder approach. Boston, USA: Pitman. Freeman, R. E., Rusconi, G., Signori, S., \& Strudler, A. (2012). Stakeholder theories: ethical 
ideas and managerial action. Journal of Business Ethics, 109(1), 1-21. https://doi.org/10.1007/s10551-012-1374-7

Grimsley, M., \& Meehan, A. (2007). E-government information systems: evaluation-led design for public value and client trust. European Journal of Information Systems, 16, 134148. https://doi.org/10.1057/palgrave.ejis.3000674

Guha, J., \& Chakrabarti, B. (2014). Making e-government work: adopting the network approach, Government Information Quarterly, 31(2), 327-336. https://doi.org/10.1016/j.giq.2013.11.008

Heeks, R. (2002). E-government in Africa: promise and practice. Information Polity, 7(2, 3), 97-114.

Heeks, R. (2008). Success and failure in e-government projects. eGov4Dev. Accessed April 15, 2018, from http://www.egov4dev.org/ success/index.shtml

Henry, N. (2013). Public administration and public affairs. Boston, MA: Pearson Press.

Hill, C., \& Lynn, L. (2016). Public management: thinking and acting in three dimensions. Los Angeles: Sage Press

Holzer, M., \& Schwester, R. (2016). Public administration. an introduction. New York: Taylor and Francis/Routledge.

Ifinedo, P. (2006). Measuring Africa's e-readiness in the global networked economy: a nine-country data analysis, International Journal of Education and Development using ICT, $1(1), 53-71$.

Jensen, T. B., Kjaergaard, A., \& Svejvig, P. (2008). Two perspectives on information system adaptation: using institutional theory with sense making. Working Paper, I-2008-06, Informatics Research Group.

Kristen, J. (2015). Stakeholders theory: how they influence the business Policy. Scholedge. International Journal of Business Policy and Governance, 2(4), 1-17.

Lau, E. (2003). Challenges for e-government development, 5th global forum on reinventing government, Mexico City, 5th (November).

Lau, E. (2005). Electronic government and the drive for growth and equity. Paris: OECD.

Mahapatra, R., \& Perumal, S. (2004). E-governance in India: a strategic framework, International Journal for Infonomics, 6(12), 21-43.

Mansell, R., \& When, U. (1998). Knowledge societies: information technology for sustainable development: New York: Oxford University Press.

Milakovich, M., \& Gordon, G. (2013). Public administration in America. Boston, MA: Wadsworth/ Cengage Learning

Muhammed, S. et al (2010). E-governance in Nigeria: a catalyst for national development, 
Being a paper, presented at fourth international conference on development studies, University of Abuja, F.C.T., Nigeria between April 14 and 15.

Mundy, D., \& Musa, B. (2010) 'Towards a framework for e-government development in Nigeria.' Electronic Journal of eGovernment, 8(2), 148-161. www.ejeg.com Nielson. Accessed April 17, 2018.

Nkwe, N. (2012) E-government: challenges and opportunities in Botswana. In International Journal of Humanities and Social Science, 2(17), 39-48.

Nwanji, T. I., \& Howell, K. E. (2007). Shareholdership, stakeholdership and the modern global business environment: a survey of the literature. Journal of Interdisciplinary Economics, 18(4), 347-361. https://doi.org/10.1177/02601079X07001800406

Nyakwende, E., \& Al Mazari, A. (2012). Factors affecting the development of e-government in Saudi Arabia. Advancing Democracy, Government and Governance, 1, 19-28 https://doi.org/10.1007/978-3-642-32701-8_3

O'Brien, J. A., \& Marakas, G. M. (2011) Management information systems (10 ${ }^{\text {th }}$ Edition). New York: McGraw-Hill/Irwin.

Okwueze, F. O. (2010). E- governance as a tool for public sector development in Nigeria. International Journal of Research in Arts and social sciences, 2.

Olatokun, W. M., \& Adebayo, B. M. (2012). Assessing e-government implementation in Ekiti State, Nigeria. Journal of Emerging Trends in Computing and Information Sciences, 3(4), 497-505

Olufemi, F. J. (2012) Electronic governance: myth or opportunity for Nigerian public administration? International Journal of Academic Research in Business and Social Sciences September, 2(9), 122-140.

Orihuela, L., \& Obi, T. (2007). E-government and e-government: towards a clarification in the usage of both concept. Amsterdam, NLD: IOS Press

Osawe, C. O. (2015). Reengineering professionalism in the public service towards service delivery Review of Public Administration and Management, 4(7), 63 -75.

Otubu, A. K. (2009). E-government and land administration in Nigeria: a recipe for Lagos state. In Charbonneau, A. (eds). Global information inequalities: bridging the information gap. Stanton Harcourt: Oxford Chandos Publishing. https://doi.org/10.2139/ssrn.1405363

Pathak, R. D., Singh, G., Belwal, R., Naz, R., \& Naz, R., \& Smith, R. F. I. (2008). E-governance and public service delivery: a comparative study of Fiji and Ethiopia. Journal of Administration and Governance, 3(1), 63-79.

Peter, G. B. (2000). Institutional theory: problems and prospects. political science series. Vienna.

Robey, D., \& Boudreau, M. C. (1999). Accounting for the contradictory organizational 
consequences of information technology: theoretical directions and methodological implications. Information Systems Research, 10, 167-185. https://doi.org/10.1287/isre.10.2.167

Rorissa, A., \& Demissie, D. (2010). An analysis of African e-government service. Government Information Quarterly, 27, 161-169. https://doi.org/10.1016/j.giq.2009.12.003

Rosenbloom, D., Kravchuk, R., \& Clerkin, R. (2009). Public administration: understanding management, politics, and law in the public sector. (Eighth Edition). New York: McGraw Hill Press.

Saunders, M., Lewis, P., \& Thornhill, A. (2009). Research methods for business students 5th ed., Essex: FT Prentice Hall.

Schuppan, T. (2009). E-government in developing countries: experiences from sub-Saharan $\begin{array}{lllll}\text { Africa. Government Information } & \text { Quarterly, 26, }\end{array}$ https://doi.org/10.1016/j.giq.2008.01.006

Scott, R. W. (1995). Institutions and organizations, Thousand Oaks, CA: Sage.

Shafritz, J. M., Russell E. W., Borick, C. P., \& Hyde, A. C. (2017). Introducing public administration. New York: Routledge/Taylor and Francis Group.

Shark, A. (2008). Reconnecting America: the role of government with technology and policy at the Crossroads. In Beyond e-government and e-democracy: a global perspective, ed. A. Shark and S. Toporkoff (1-10). Charleston, SC: Public Techonoloy Institute and ITEMS International, Book-Surge LLC.

Shark, A. (2016). Technology and public administration. In Holzer, M., \& R. W. Schwester (2016). Public administration: an introduction. New York: Taylor and Francis/Routledge Press, PP. 342-376.

West, D. (2004). E-government and the transformation of service delivery and citizen attitudes. Public Administration Review, 64(1), 15-27. https://doi.org/10.1111/j.1540-6210.2004.00343.x

Wong, W., \& Welch, E. (2004). Does e-government promote accountability? A comparative analysis of website openness and government accountability. Governance: An International Journal of Policy, Administration, and Institutions, 17(2), 275-297. https://doi.org/10.1111/j.1468-0491.2004.00246.x

World Bank. (2001) Issue note: e-government and the World Bank. November 5. UNPA and ASPA (2001) Benchmarking e-Government: A Global Perspective.

Ya, N. A., \& Van Wart, M. (2016). Building business-government relations: a skills approach. New York: Routledge Press.

Yusuf, M. (2005). Information and communication technology, and education: an analysis of the Nigerian national policy for information technology. International Education Journal, 6(3), 316-321. 


\section{Macrothink}

Journal of Public Administration and Governance ISSN 2161-7104 2018, Vol. 8, No. 3

Zhang, J., Dawes, S., \& Sarkis, J. (2005). Exploring stakeholder's expectations of the benefits and barriers of e-government knowledge sharing. The Journal of Enterprise Information Management, 18(5), 548-567. https://doi.org/10.1108/17410390510624007

Zussman, D. (2002). Public policy forum commonwealth centre for electronic governance integrating government with new technologies: how is technology changing the public sector? Ottawa, Canada. February.

\section{Copyright Disclaimer}

Copyright for this article is retained by the author(s), with first publication rights granted to the journal.

This is an open-access article distributed under the terms and conditions of the Creative Commons Attribution license (http://creativecommons.org/licenses/by/4.0/). 